NBER WORKING PAPER SERIES

\title{
ESTIMATING PRICE ELASTICITIES WHEN THERE IS SMUGGLING: THE SENSITIVITY OF SMOKING TO PRICE IN CANADA
}

\author{
Jonathan Gruber \\ Anindya Sen \\ Mark Stabile
}

Working Paper 8962

http://www.nber.org/papers/w8962

\author{
NATIONAL BUREAU OF ECONOMIC RESEARCH \\ 1050 Massachusetts Avenue \\ Cambridge, MA 02138 \\ May 2002
}

We are grateful to Mark Bergman for excellent research assistance. Sen gratefully acknowledges funding support from the Centre for Behavioural Research and Program Evaluation of the Canadian Cancer Society / National Cancer Institute of Canada. The views expressed herein are those of the authors and not necessarily those of the National Bureau of Economic Research.

(C) 2002 by Jonathan Gruber, Anindya Sen and Mark Stabile. All rights reserved. Short sections of text, not to exceed two paragraphs, may be quoted without explicit permission provided that full credit, including (C) notice, is given to the source. 
Estimating Price Elasticities When there is Smuggling:

The Sensitivity of Smoking to Price in Canada

Jonathan Gruber, Anindya Sen and Mark Stabile

NBER Working Paper No. 8962

May 2002

JEL No. I1, H2

\begin{abstract}
A central parameter for evaluating tax policies is the price elasticity of demand for cigarettes. But in many countries this parameter is difficult to estimate reliably due to widespread smuggling, which significantly biases estimates using legal sales data. An excellent example is Canada, where widespread smuggling in the early 1990 s, in response to large tax increases, biases upwards the response of legal cigarette sales to price. We surmount this problem through two approaches: excluding the provinces and years where smuggling was greatest; and using household level expenditure data on smoking, where there is a downward bias to estimated elasticities from smuggling. These two approaches yield a tightly estimated elasticity in the range of -0.45 to -0.47 . We also show that the sensitivity of smoking to price is much larger among lower income Canadians. In the context of recent behavioral models of smoking, whereby higher taxes reduce unwanted smoking among price sensitive populations, this finding suggests that cigarette taxes may not be as regressive as previously suggested. Finally, we show that price increases on cigarettes do not increase, and may actually decrease, consumption of alcohol; as a result, smuggling of cigarettes may have raised consumption of alcohol as well.
\end{abstract}

Jonathan Gruber

Department of Economics

MIT, E52-355

50 Memorial Drive

Cambridge, MA 02142-1347

and NBER

gruberj@mit.edu
Anindya Sen

University of Waterloo
Mark Stabile

Department of Economics University of Toronto

150 St. George Street

Toronto, ON

Canada M5S 3 G7 
One of the most important sources of government revenue raising around the world, both economically and politically, is the taxation of tobacco products. A central determinant of the optimal level of tobacco taxation is the price sensitivity of demand for cigarettes. This parameter has been estimated repeatedly in the U.S. context, with a consensus estimate of 0.4 to 0.5 (Chaloupka and Warner, 2000), but with recent estimates at 0.6 (Gruber and Koszegi, 2000,2002; Yurekli and Zhang, 2000). But estimating this parameter in many other countries faces a fundamental difficulty which is not a real barrier in the U.S. context: widespread smuggling. Smuggling of cigarette products can significantly bias price elasticities estimated using legal sales data, as the shift from legal to illegal product will appear to be a price sensitivity of overall demand.

A classic example of this problem is the experience of Canada in the early 1990s. Between 1989 and 1993, excise taxes at the federal and provincial level rose sharply from an average of $\$ 1.90$ per pack to $\$ 3.50$ per pack. In response to these large tax increases, there was an enormous increase in smuggling in Canada through legal export and illegal reimport. Indeed, by the typical measure of smuggling used to describe this experience, smuggled cigarettes represented roughly one-third of all domestic cigarette consumption at their peak. Then, in the face of enormous smuggling, federal and provincial taxes were halved in 1994. In recent years, however, there has again been a trend towards increasing these taxes in response to reports that 
the decline in cigarette prices has resulted in a significant increase in smoking by Canadians. ${ }^{1}$

In this paper, we provide a framework for estimating elasticities in the context of widespread smuggling. In particular, we estimate demand models for Canada that attempt to correct for the smuggling problem in two different ways. First, we use legal sales data, and exclude the regions and years where the smuggling problem was the worst. Second, we use micro-data on consumer cigarette expenditures. As we point out below, the bias from smuggling in legal sales and consumer expenditure data work in opposite directions, so the estimates from these two sources bound the truth. In fact, we find that the estimates from these two sources are quite divergent initially, but become more similar (in the range of -0.45 to -0.47 ) when smuggling provinces/years are excluded. This suggests that a fairly reliable estimate of the elasticity of demand for cigarettes can be provided for Canada despite the large smuggling problem.

We then extend the analysis in two important directions. First, we estimate the price sensitivity of demand by different income groups. It is well known that lower income groups spend a larger share of their incomes on cigarettes, so that tobacco taxes have been traditionally viewed as regressive. But, as we discuss further below, under alternative (plausibly more reasonable) models of the smoking decision, tobacco taxes may not be regressive if lower income groups are much more price sensitive. It therefore becomes critical to explore the price sensitivity of smoking by income group. We do so using our micro-data on tobacco expenditure,

\footnotetext{
${ }^{1}$ For further details please see "Martin hints at tobacco price increase: with conditions." (Canadian Press Newswire, September $\left.19^{\text {th }}, 1996\right)$, "Governments raise tobacco taxes, Ottawa restricts tobacco ads." (Canadian Press Newswire, November $28^{\text {th }}, 1996$ ) and "Provinces with low tobacco taxes had higher smoking rates." (Canadian Press Newswire, April 17 $\left.7^{\text {th }}, 1995\right)$.
} 
and show that lower income groups are much more price sensitive than higher income groups; this finding suggests that tobacco taxes in fact may not be regressive in the context of plausible alternative models.

Second, we estimate the impact of cigarette price changes, and of smuggling of cigarettes, on demand for alcohol. If cigarettes and alcohol are substitutes, then one potential advantage of smuggling is that it reduces a shift into this alternative "bad". But, if these activities are complements, then a further cost of smuggling is that it increases not only cigarette consumption but also alcohol consumption as well. We find in that legal sales data that cigarettes and alcohol are complements; higher cigarette taxes lead to lower alcohol consumption, and that smuggling lead to increased alcohol consumption. We do not find confirmatory evidence in the expenditure data, however; thus, while it is clear that these goods are not substitutes, there is mixed evidence on whether they are complements.

Our paper proceeds as follows. Part I provides some background on the literature on the price elasticity of demand for cigarettes, and on cigarette taxation in Canada and the U.S. Part II describes our data, and Part III discusses our empirical methodology. Part IV presents our basic results on demand elasticities. Part V discusses estimated elasticities by income group, and Part VI presents evidence on the substitutability of cigarettes and alcohol. Part VII concludes.

\section{Part I: Background}

There is an enormous literature in the United States that has been devoted to estimating the price elasticity of demand for cigarettes. This literature has taken advantage of the fact that there is substantial variation in the price of cigarettes across the U.S. states, and significant 
changes within states over time, due to variable state excise tax policies. For example, in 2001, the excise tax on cigarettes varied from a low of 2.5 cents in Virginia to a high of $\$ 1.11$ in New York.

The U.S. literature is reviewed in detail in Chaloupka and Warner (2001). The consensus estimate of the price elasticity of demand in their review is -0.45 . Recent estimates, using updated data through the 1990s, have suggested that the elasticity may be higher. Gruber and Koszegi estimate an elasticity of -0.6 in legal sales data, and of -0.66 in micro-data on consumption (Gruber and Koszegi, 2000, 2001); Yurekli and Zhang (2000) estimate an elasticity of -0.62 in legal sales data.

Another issue that has been addressed in the U.S. is the impact of smuggling on elasticity estimates. A number of articles have included indirect controls for smuggling in the United States. A typical example is the approach taken in a recent paper by Farrelly, Pechacek, and Chaloupka (2001). They estimate models of aggregate cigarette sales by U.S. state, and they include in their models controls for "importing" and "exporting" which are the gap in price between the state and its neighbors, weighted by the population densities near the border of the state. This type of approach will capture price incentives for smuggling, and indeed the results using this approach suggest that there are flows of sales from high tax to low tax states. Other papers have augmented this approach by including the price differentials between the state and the low price tobacco producing states (Kentucky, North Carolina, and Virginia; see, for example, Becker, Grossman and Murphy (1984) or Yurekli and Zhang (2000)).

But this approach provides a somewhat crude proxy for the actual amount of smuggling. To the extent that smuggling is related to non-price factors, it will not be captured. Even if price 
is the only determinant of smuggling, the actual functional form of how price relates to smuggling may differ from the ones imposed by these models (e.g. nonlinear terms of the price, or different functional forms of population distribution, may be relevant). In the U.S., where smuggling is a relatively minor issue, this may not be an important problem for estimating demand elasticities; but in Canada, as noted below, it could be a more significant issue.

There are two reasons to think that the elasticity estimates from the U.S. may not apply in the Canadian context. First, prices are much higher in Canada. On average, over the 1980s and 1990 s, the real price of cigarettes was $\$ 1.86$ in the U.S. (in $\$ 1999$ ). It was roughly $25 \%$ higher at \$2.33, in Canada (1999 U.S. \$) over the same time period. There is little evidence on how the elasticity of demand varies with price. But the general presumption is that the elasticity of demand falls with prices; at higher prices, only the most addicted smokers remain in the smoking pool.

A second, and critical, difference is smuggling. There is modest cross-state smuggling in the U.S., which has been estimated to be on the order of 3-4\% of consumption in the 1970 s (Thursby and Thursby, 2000), and 6\% of tax revenues in 1995 (Yurekli and Zhang, 2000). But smuggling of cigarettes into Canada in the 1990s was on a very different scale. In the face of rising taxes in the early 1990s, smuggling of cigarettes increased dramatically through a particular mechanism: legal export to the U.S., and then legal re-import across the U.S./Canadian border, in particular through Indian reservations which straddle the border. There exists evidence which suggests that virtually all cigarettes smuggled into Canada in the early and mid 1990s, were previously exported from Canada to the United States, and previous research have employed these exports as a proxy for smuggling (see Galbraith and Kaiserman, 1997 for 
example). Further support for this assumption stems from the lawsuit launched by the Government of Canada in October 1999 in the United States Federal Court against RJRMacdonald Inc., RJ Reynolds Tobacco Holdings Inc., and several related companies claiming that the RJ Reynolds companies conspired with known distributors and smugglers to illegally smuggle their tobacco products into Canada. ${ }^{2}$

The typical means of estimating contraband sales in Canada in the early 1990s is therefore to consider increases in cigarette exports relative to the pre-1990 baseline. This is shown in Figure 1. Legal sales of cigarettes, after slowly declining until 1990 (mirroring the decline in the U.S.), suddenly dropped precipitously until 1993, before jumping back up again in 1994. There is a mirror-image increase in cigarette exports over these years. As Figure 2 shows, exports rose from a pre-1990 level of less than 1.5\% of legal sales to a level in 1993 of roughly half of legal sales, before plummeting again in 1994 as taxes declined. This suggests smuggling on a much larger scale than has been seen in the U.S. context.

This period is also the time period of greatest movement in cigarette taxes (and prices). As shown in Figure 3, average excise and sales taxes on cigarettes rose steeply until 1993, then fell sharply in 1994 in response to growing concerns of the effects of smuggling. In particular, there was a decline in both federal excise taxes and provincial taxes in the five eastern provinces where smuggling was considered to be significant (Ontario, Quebec, New Brunswick, Nova

\footnotetext{
${ }^{2}$ The actual press release can be found at http://canada.justice.gc.ca/en/news/nr/1999/doc_24494.html. On June 30, 2000, the United States District Court dismissed Canada's case on points of law, citing the Revenue Rule as the reason for dismissal. In response, the Government of Canada filed a notice of appeal on July 28th 2000.
} 
Scotia, and Prince Edward Island) from February 9 to April 15, 1994. ${ }^{3}$ The federal government cut its excise tax (levied at the manufacturer's end) from $\$ 10.36$ to $\$ 5.36$ per carton of 200 cigarettes in February 1994. After the federal tax cut, the five eastern provinces dropped their provincial tax rates (levied at the retailer's end) as well. Quebec dropped its tax rate in February 1994, and it was soon followed by New Brunswick, Ontario, Prince Edward Island and Nova Scotia. The federal government then cut the cigarette excise tax even further in these five provinces. $^{4}$ By April 1994, the combined federal and provincial cuts had reduced tax rates in these provinces by between $\$ 14$ and $\$ 21$ per carton (Hamilton et al, 1997a). The above policy details indicate which provinces were the hardest hit by smuggling: those eastern provinces in which it was easiest to re-import legally exported cigarettes to the U.S..

The few studies that have attempted to estimate the price elasticity of demand in Canada either fail to address the impact of smuggling or suffer from other shortcomings. Reinhardt and Giles (2001) find a price elasticity of -0.62 . Their study uses time series national level data between 1968 to 1990 , which precludes the serious smuggling period of the early nineteennineties. However, they rely solely on national time series variation; any other contemporaneous trends in the demand for cigarettes (such as the overall fall in demand that was observed in the U.S. as well) could bias their estimates.

Galbraith and Kaiserman (1997) also employ national time series data on legal cigarette

\footnotetext{
${ }^{3}$ The Canadian prime minister, Jean Chretien, stated that smuggling was attracting organized-crime gangs, increasing the danger to law-enforcement officials and others as smugglers use assault weapons, creating hardship for owners of small stores that rely heavily on cigarette sales, and costing millions in lost tax revenue to provincial and federal treasuries (Gunby, 1994).

${ }^{4}$ Unlike other federal taxes, the federal government sets province specific federal excise taxes on cigarettes. We discuss this in further detail below.
} 
sales and prices, their data comes from 1980 to 1994. In order to account for the smuggling between 1990 to 1994, the authors combine legal sales figures with export numbers to come up with an estimate of total consumption. They find short run elasticities of legal and total consumption with respect to legal prices to be -1.01 and -0.40 , respectively. Their model does control for linear time trends in smoking, but it is unclear if this is sufficient to control for underlying trends in smoking demand that might be correlated with (but not caused by) price changes.

Hamilton et al, (1997b) examine the response to changes in cigarette prices in Canada between 1985 and 1995. They use micro data on cigarette consumption over time and across provinces and estimate elasticities in the range of -.3 . These estimates exploit the significant variation in prices across the provinces over the 1990s, but again do not control for the impact of smuggling over this period. Nor do they include province fixed effects to control for differences across provinces in tastes for smoking.

In short, none of the Canadian literature has approached the sophistication of the U.S. literature, which uses "difference-in-difference" estimates based on tax variation within states over time to control for state-specific tastes for smoking and for national trends in smoking. And the issue of smuggling has also either been ignored or addressed in a rudimentary fashion. Thus, it seems to us appropriate to revisit a Canada-specific estimate of the elasticity of cigarette demand. It is this estimate that we pursue below. 


\section{Part II: Data}

\section{Tax, Price, and Legal Sales Data}

There exists significant cross-province and time-series variation in both federal and provincial cigarette taxes. Federal taxes consist of excise taxes, excise duties, and sales taxes (the federal sales tax until 1991, and the goods and services tax (GST) thereafter). There is considerable variation in these taxes over time. Moreover, unlike other federal taxes, federal taxes on cigarettes also differ across provinces at a point in time. Specifically, while federal excise duties and sales taxes are similar across provinces there are pronounced differences in federal excise taxes after February 1994. Federal excise taxes dropped from $\$ 10.35$ per 200 cigarettes to \$5.35 (nominal \$) in British Columbia, Alberta, Saskatchewan, Manitoba, and Newfoundland. In contrast federal excise taxes fell from $\$ 10.35$ to $\$ 0.75, \$ 0.35, \$ 3.35, \$ 3.35$, and \$1.10 in Ontario, Quebec, New Brunswick, Nova Scotia, and Prince Edward Island, respectively. Provinces also levy their own tobacco tax and sales taxes, and further provincial variation results from whether or not a provincial sales tax is applied to tobacco products. ${ }^{5}$ The result of this web of taxes is that there is significant variation in effective excise and sales taxes on cigarettes within provinces over time.

Average prices (nominal) per 200 cigarettes for each province between 1994 to 1999 were obtained from Statistics Canada. Average province specific prices for other years between 1981 to 1997 were then extrapolated using cigarette price indices for each province from

Statistics Canada. The problem with computing prices in this manner, however, is that the index

\footnotetext{
${ }^{5}$ Data on federal and provincial taxes from 1971 onwards were obtained from the Ministry of Finance, and counter checked against relevant editions of the National Finances, and Provincial and Municipal Finances.
} 
is only available annually, and there are important movements in taxes (and therefore prices) within the year. We therefore compute a pre-tax annual price by subtracting from the nominal price the average excise and sales tax level during the year. We then compute a new after-tax price by adding to this annual average pre-tax price the monthly value of the excise and sales tax.

We obtained data on total legal sales of cigarettes for each province between 1981 to 1999 from the National Clearinghouse on Tobacco and Health Program, an organization funded by the federal government as well as the provinces, which acts as a public repository for data relevant to tobacco control. Our dependent variable, legal cigarette sales per capita, is created by dividing sales by the population age 15 and older in each province and year.

Table 1 contains average real prices and taxes (in \$1992) per 200 cigarettes, and legal sales per capita, from the end points of the sample (1981 and 1999) separately for provinces where there was less smuggling (British Columbia, Alberta, Saskatchewan, Manitoba, and Newfoundland) and where smuggling was concentrated (Ontario, Quebec, New Brunswick, Nova Scotia, and Prince Edward Island). ${ }^{6}$ We also divide this period into several sub-periods of interest: 1981 to 1989 (before smuggling was a major issue); 1990-1993 (the period of major smuggling); 1993-94 (the period of reaction to the smuggling problem); and 1995-1999. In 1981, at the start of our period, these two sets of provinces looked quite similar in terms of per capita

\footnotetext{
${ }^{6}$ Nominal prices and taxes were deflated with province specific consumer price indices, obtained from Statistics Canada.

${ }^{7}$ This division comes from the fact that the primary conduits for smuggling cigarettes into Canada were across the St. Lawrence River and Indian reserves that separate the eastern provinces (Ontario, and Quebec and the Maritimes) from the U.S. ("Contraband cigarettes hurt Canada's cigarette makers." The Economist, v 330, Jan 15 1994. p. 68). Moreover, this division is confirmed by the fact that our set of "smuggling" provinces is exactly the set where both provincial and federal taxes were slashed in response to the smuggling "crisis"; thus, these are the provinces for which policy-makers viewed the smuggling problem as worst. Smuggling apparently was not significant in Newfoundland due to it's distance from the U.S. border. This explains why it did not lower its tobacco taxes in 1994 along with other eastern provinces.
} 
legal sales, taxes, and prices. They also had similar changes in sales, taxes, and prices over the 1981-1989 period. Over the 1990-1993 period, the change in price and tax was also similar in the two sets of provinces, but there were quite different changes in legal sales. In the nonsmuggling provinces, legal sales fell by $25 \%$; but, in the smuggling provinces, sales fell by $40 \%$. This higher price sensitivity in the "smuggling provinces" is very consistent with the notion of smuggling into these provinces, eroding the legal sales base.

From 1993-1994, there were much larger reductions in taxes and prices in the smuggling provinces; as noted above, these were the response to the smuggling problem. ${ }^{8}$ There was an associated dramatic increase in legal sales in those provinces relative to the nonsmuggling provinces; this response to the price change once again highlights the impact of smuggling on price sensitivity of legal sales. Finally, in the last period, taxes began to rise again in the smuggling provinces, and legal sales to fall. By 1999, the result of these actions was that taxes and prices were significantly lower in the smuggling provinces, and per capita consumption was significantly higher.

The results in Table 1 confirm that smuggling was a major problem in Canada in the 1990-1993 period. Since price changes were similar over the 1990-1993 period in the two sets of provinces, we can infer that the $15.45 \%$ larger drop in legal sales in the smuggling provinces represented the impact of smuggling. Multiplying this by per capita sales, and then by population, we obtain an estimate of a 4.6 billion reduction in legal cigarette sales. According to

\footnotetext{
${ }^{8}$ This decline in cigarette taxes in non-smuggling provinces was primarily due to the drop in federal excise taxes from $\$ 10.35$ per 200 cigarettes to $\$ 5.35$ (nominal $\$$ ), as other relevant federal and provincial taxes remained unchanged. As discussed earlier, the fall in federal excise taxes in the smuggling provinces was much more dramatic. Provincial tobacco taxes fell from: $\$ 13$ to $\$ 3.40$ in Ontario; $\$ 13.76$ to $\$ 2.76$ in Quebec; $\$ 13.60$ to $\$ 6.60$ in New Brunswick; $\$ 13.60$ to $\$ 6.60$ in Nova Scotia; and $\$ 19.60$ to $\$ 10.36$ in Prince Edward Island, respectively. Federal excise duties remained constant across all provinces at $\$ 5.50$.
} 
the export data cited earlier, over the 1990-1993 period exports of cigarettes averaged 7.6 billion per year. This represented a rise of 5.3 billion per year over the 1988-1989 (“pre-smuggling”) baseline. So our estimate using the legal sales data is only about $13 \%$ lower than the export estimate of smuggling. Moreover, our estimate should be a lower bound, since we assume zero smuggling into all of the other provinces in Canada.

\section{FAMEX Data}

Our second data source is the Canadian Survey of Family Expenditure (FAMEX). We use information from this survey to track household cigarette expenditure over time and across Canada. We use every available survey year between 1982 and 1998 which comprises of 1982, 1984, 1986, 1990, 1992, 1996, 1997, and 1998. The survey is a national survey, although some of the survey years focus on urban centres, while others include both urban and rural populations. $^{9}$

Each survey collects information on how much the household spent on cigarettes (as separate from other tobacco products) in that year. We use this question as our measure of cigarette expenditure. The survey also collects limited demographic information which we include in our analysis, including the after tax income of the household, the family size of the household, and the sex of the head of the household. The survey also reports total expenditures on all goods by the household, which we use later in our analysis. While education information is available in earlier surveys, these questions were unfortunately dropped from the later years of

\footnotetext{
${ }^{9}$ We re-run all specifications limiting the sample to only urban populations, and also including urban/rural controls. Our finding are robust to these alternate specifications.
} 
the survey and so we do not include education controls here.

While ideally we would like to know the province of residence, the FAMEX data reports consistent information for region of residence only. The region variable groups the Maritime provinces together and the Prairie provinces together. Therefore the data contain information on five regions: the Maritimes, Quebec, Ontario, the Prairies, and British Columbia. Beginning in 1986 the data contain a separate regional identifier for Alberta and beginning in 1992 the data identify all 10 provinces. In our analysis we use the five regional dummies available throughout our sample as regional controls. In order to assign cigarette taxes to provinces we exploit the maximum amount of regional information available in that survey year and when necessary assign the average of the tax rates across the region when the specific province is not identifiable. We drop a small number of observations (362) for which regional information is missing. All expenditure and income information is transformed into 1992 Canadian dollars. The resulting data set consists of 81,479 observations across eight survey years.

\section{Means}

Means of our data sets are show in Table 2. On average, Canadians consumed 2188.8 cigarettes on an annual basis at a per-carton real (1992) price of $\$ 31.21$, paying a tax of $\$ 21.28$. There is considerable variation in real taxes as the sample minimum and maximum are $\$ 5.31$ and $\$ 42.91$, respectively. The sample mean of taxes as a share of price is $66.01 \%$, with minimum and maximum values of $44.40 \%$ and $80.65 \%$, respectively. In the FAMEX data, average cigarette expenditure was \$553 in 1992 dollars. Forty-four percent of households spent some amount on cigarettes in the past year and among smokers average expenditure was \$1253 (1992 dollars). 


\section{Part III: Empirical Methodology}

Our basic empirical methodology follows that used in the previous literature. We use the legal sales data to estimate models of the form:

$$
\text { SALES }_{\mathrm{jt}}=\alpha+\beta \text { PRICE }_{\mathrm{jt}}+\delta_{\mathrm{j}}+\tau_{\mathrm{t}}+\delta_{\mathrm{j}}{ }^{*} \text { TIME }+\varepsilon
$$

where SALES is cigarettes sold per capita in province $\mathrm{j}$ in year $\mathrm{t}$; PRICE is the cigarette price; $\delta_{\mathrm{j}}$ and $\tau_{\mathrm{t}}$ are fixed effects for province and year, respectively; and TIME is a linear time trend. By including province fixed effects, we control for any fixed differences in tastes for smoking across provinces. Likewise, by including fixed time effects, we control for any national changes in smoking behavior which may be correlated with, but causally unrelated to, tax changes. But the problem with those controls alone, when the panel is long, is that there may be slowly moving trends within provinces that are correlated with both smoking and cigarette prices; as Gruber and Koszegi (2000) discuss for the U.S., there is a very significant impact of such trends on price elasticity estimates. Thus, we include linear province-specific time trends in our models as well. Finally, we also control for provincial unemployment rates and real per capita income in order to proxy business-cycle effects. We estimate this model in levels; results from log-log models are quite similar.

One problem with this model is that price may be endogenous. That is, tobacco companies may set province-specific prices in reaction to province-specific shocks that affect the taste for smoking. We therefore estimate an instrumental variables version of equation (1), where we use province/year taxes as instruments for prices.

The major problem that remains with this framework, as highlighted above, is smuggling. If there is significant smuggling, then the elasticity we estimate with legal sales data will 
overstate the true elasticity, since part of the response to price increases is to exit the legal market. That is, suppose that true total consumption is:

$$
\mathrm{SMOKE}_{\mathrm{jt}}=\mathrm{SALES}_{\mathrm{jt}}+\mathrm{SMUGGLE}_{\mathrm{jt}}
$$

where SALES is legal sales, as above; SMUGGLE is smoking of smuggled cigarettes; and SMOKE is total smoking. Then the estimated elasticity of sales with respect to the price is:

$$
\begin{aligned}
& \delta \underline{\mathrm{SALES}}=\delta \underline{\mathrm{SMOKE}}-\delta \underline{\mathrm{SMUGGLE}} \\
& \text { SPRICE } \quad \delta \text { PRICE } \quad \text { SPRICE }
\end{aligned}
$$

Since the first term on the right hand side is negative, and the second term is positive, the elasticity of sales with respect to price will over state the true elasticity of smoking with respect to price.

How can one address this problem? There are three approaches. The first is to try to include a measure of smuggled consumption directly into the model, to control for this omitted factor. The problem is that the only measure that we have available is export data, but these are national data and there is no way to use them to derive a province-specific amount of smuggling. The second approach is to estimate the elasticity over times and places where smuggling is not an issue. We have already presented evidence that the worst smuggling in Canada was in the eastern part of the country. In terms of the specific time period, we assume that significant movement in contraband cigarettes from the U.S. occurred during 1990-94, which is consistent with previous research (Galbraith and Kaiserman, 1997). Therefore, we can reestimate this model excluding observations from these eastern provinces over the 1990-94 period.

But the disadvantage of this approach is that it is once again relatively crude. We can't definitely define either the times or the places where smuggling was worst. And the broader the 
cut out of our data to account for this, the more true variation in prices we lose, since the 1990s was the period of the greatest movement in cigarette prices.

We therefore also rely on a third approach: using actual cigarette expenditure data. The advantage of cigarette expenditure data is that the bias is the opposite of that documented for legal sales data: smuggling will lead to an understatement of the elasticity using expenditure data. This is because our regressions use the legal price of cigarettes, which overstates the effective price of consumption in the smuggling provinces. Thus, there is systematic measurement error in the price data that leads to a downwards bias to the estimated elasticity.

In the cigarette expenditure data, we run similar regressions to those above. The dependent variable is household cigarette expenditures (including zeros if there is no cigarette expenditure). We also show results below where we estimate separate models for any smoking and the conditional amount smoked. As above, we control for fixed effects for each region and for each year, as well as region-specific linear time trends. We also control for some of the household characteristics available in this micro-data: after tax household income, the square of after tax income, the sex of the household head and the family size.

\section{Part IV: Basic Results}

Our basic estimates from the legal sales data, with no attempt to correct for smuggling, are shown in the first two column of Table 3, which shows a linear model which relates cigarette sales per capita to the price (instrumented by tax). We estimate that for every $\$ 1$ rise in (real) price, there is a 49.95 reduction in cigarette consumption per capita. The implied elasticity is 0.72. This estimate is somewhat larger than the elasticity estimates for the U.S.; given that prices 
are so much higher in Canada, the presumption discussed above was that the elasticity would actually be lower. However, there is no correction for smuggling bias.

In column (2), we attempt our first correction: excluding the smuggling provinces (the eastern provinces during the $1990-94$ period). Doing so, as we expected, we find a fall in the elasticity, which is now estimated to be -0.47 . Thus, correcting for smuggling in this way does appear to have an important impact on the estimated elasticities. In particular, it moves them into the range estimated for the U.S.

We then turn, in Table 4, to comparable estimates using the FAMEX consumption data. Column (1) shows the estimated impact of price (instrumented by tax) on dollars of cigarette expenditure. The coefficient estimates show the impact of a one dollar price increase on expenditures; the standard errors are in parentheses. Below each estimate is the price elasticity of sales implied by this consumption response, at the mean price and quantity; this elasticity is computed as $\beta / \underline{C}-1$, where $\beta$ is the estimated coefficient and $\underline{\mathrm{C}}$ is the sample mean of consumption. We estimate that each dollar price increase leads to an increase in annual cigarette expenditures of 10 dollars, for an implied elasticity of -0.45 .

Columns (2) and (3) decompose this response into its intensive and extensive margins. We do so by modeling separately a dummy for the presence of any tobacco expenditure in the household, and the level of spending conditional on there being any household spending (elasticities are almost identical if we use log of conditional spending). We find that there is only a small and insignificant effect of prices on the presence of any tobacco expenditure in the family. But there is a large elasticity of conditional expenditures of -0.41 . Thus, it appears that almost all of the response of consumption to price changes occurs through reductions in 
consumption and not quitting smoking; this stands in contrast to the U.S. evidence, which suggests that both margins are responsible in similar proportions for the sensitivity of smoking to price (e.g. Evans, Ringel and Stech, 1998).

In columns (4)-(6), we repeat these estimates, excluding once again the smuggling province/years. This change in sample, interestingly, has essentially no effect on the estimated elasticities. This suggests that the bias from mismeasured prices through smuggling is quite modest.

Putting these two sets of estimates together, we have a well defined range of price elasticities from -0.45 to -0.47 . It is clear that the estimates obtained from the legal sales data, without any correction for smuggling, are too large. But, once the smuggling provinces and years are removed, the legal sales data estimates are comparable to those from the expenditure data. The similarity of the estimates using these two alternative approaches is comforting and suggests we are obtaining the "true" price elasticity that is not tainted by smuggling.

\section{Part V: Estimates by Income Group}

\section{Motivation}

A primary consideration in the policy debate over excise taxation is the potential regressivity of tobacco taxes. Lower income groups spend a much larger share of their incomes on cigarettes than do higher income groups. This is illustrated for Canada in Table 5. The first column of this table shows the distribution of cigarette expenditures as a share of after-tax income by after-tax income quartile in 1998 . While the lowest income quartile spent $4 \%$ of aftertax income on cigarettes, the highest income quartile spent only $1 \%$ of after tax income. 
This seeming inequity is much smaller than it appears when considered from the lifetime perspective, however. The lifetime burden of excise taxes is typically much smoother than the annual incidence, since income levels vary more over a lifetime than smoking levels (Poterba, 1989). The third column of Table 5 follows Poterba (1989) in using cigarette expenditures as a share of consumption expenditures (the appropriate proxy for lifetime income in the life cycle model). The distribution of expenditures is much smoother with the lowest expenditure quartile spending $2.3 \%$ on cigarettes and the highest quartile spending $0.9 \%$ on cigarettes.

These facts would suggest that a tax on cigarettes would be very regressive. But Gruber and Koszegi (2002) question this traditional approach to tax incidence. They note that this approach is only valid under the rational addiction model of Becker and Murphy (1988). This model presumes that agents decide to smoke in the same way they decide on other things: they trade off the long-term costs of smoking against the immediate pleasures, all the while taking into account the addictive properties of nicotine. In particular, Becker and Murphy model the act of smoking as the building of an addiction stock. The more cigarettes smoked today, the greater the addiction capital tomorrow. High addiction capital lowers average utility but raises the marginal utility to smoking. In this way, smoking lowers future utility but also increases the craving for another cigarette. The key feature of any addiction model is on how people deal with this intertemporal problem. In the original Becker-Murphy formulation individuals discounted the future exponentially, meaning that they discount k-periods forward by $\delta^{\mathrm{k}}$, where $\delta$ is the perperiod time discount factor.

Gruber and Koszegi $(2001,2002)$ develop an alternative to the Becker and Murphy model which embeds within the Becker-Murphy stock addiction framework preferences that are time 
inconsistent, following Laibson (1997) and O’Donoghue and Rabin (1999). In this quasihyperbolic formulation, next period is discounted by $\beta \delta$, the following period by $\beta \delta^{2}$, and $\mathrm{k}$ periods in the future by $\beta \delta^{\mathrm{k}}$, where $\beta<1$ is an extra discount factor that changes the discounting of this period relative to the entire future. The key feature of such a hyperbolic model is that individuals will have self-control problems. Specifically, a sophisticated hyperbolic individual (one who knows that he discounts hyperbolically) would like to smoke less in the future than he actually can. The problem arises because he is patient about the future (the relative discount rate between future periods is $\delta$ ), but impatient about the present (the relative discount rate between today and tomorrow is $\beta \delta<\delta$ ). This means that when the future arrives he will end up making more impatient choices (i.e. smoke more) than he would like to from today's vantage point. As Gruber and Koszegi show, the discounted utility of a sophisticated hyperbolic consumer can rise if a tax is imposed. The reason is that the tax serves as a self-commitment device. By forcing a reduction in the smoking in the future, the tax allows the sophisticated hyperbolic agent to do something they would not be otherwise be able to do.

Distinguishing these models empirically is difficult, as they both predict that smokers would be price sensitive. So the evidence in this paper does not speak to the appropriate model. But the available evidence is much more consistent with the Gruber and Koszegi formulation. Laboratory experiments document overwhelmingly that consumers are time inconsistent (Ainslee, 1992). In experimental settings, consumers consistently reveal a lower discount rate when making decisions over time intervals further away than for ones closer to the present, raising the specter of inter-personal conflict over decisions that have implications for the future.

In the context of smoking, there is indirect evidence for time inconsistency that is 
reviewed in Gruber and Koszegi $(2001,2002)$. A hallmark of time inconsistency is the use of self-control devices. And there is substantial evidence that self-control devices are frequently employed to quit smoking; people regularly set up socially managed incentives to refrain from smoking by betting with others, telling others about the decision, and otherwise making it embarrassing to smoke (Prochaska et al., 1982). Various punishment and self-control strategies are recommended by both academic publications (Grabowski and Hall, 1985) and self-help books (CDC, various years). Such self-control devices are not needed by a time consistent agent; while such an agent would obviously like to make quitting as costless as possible, lowering the utility of an undesired alternative is irrelevant for decision making. ${ }^{10}$

A final piece of evidence is an econometric test in Gruber and Mullainathan (2002). They argue that one means of empirically distinguishing time inconsistent agents from time consistent agents is the impact of cigarette taxation on their measured well-being. Time consistent smokers will be made worse off by cigarette taxation, by the standard arguments that underlie the Becker-Murphy model. But time inconsistent agents can be made better off by higher taxes, as they provide the self-control device the agents demand. Gruber and Mullainathan use data on self-reported well-being from the General Social Surveys of the United States and Canada, matched to information on cigarette excise taxes, to show that higher levels of excise taxes raise reported well-being among smokers, but not among others, which provides some empirical

\footnotetext{
${ }^{10}$ An alternative formulation of time inconsistency is the naive case, where individuals do not recognize their own self-control problems (O’Donoghue and Rabin, 1999). One feature that distinguishes naive timeconsistent agents from time-inconsistent agents is an inability to realize desired future levels of smoking. In fact, unrealized intentions to quit at some future date are a common feature of stated smoker preferences. For example, among high school seniors who smoke more than one pack/day, the smoking rate five years later among those who stated that they would not be smoking (74 percent) is actually higher than the smoking rate among those who stated that they would be smoking (72 percent) (U.S. Department of Health and Human Services, 1994).
} 
support for the time inconsistent model.

Gruber and Koszegi (2002) show that, if smokers are time inconsistent, the standard measures of tax incidence are wrong. In particular, the incidence of a tax is no longer simply proportional to the ex ante distribution of expenditure shares. Rather, the self-control benefits of the tax across income groups must be taken into account. If a tax provides self-control benefits, then the fact that the poor smoke more means that they derive a larger self-control benefit from a higher tax. That is, since the tax now serves a positive role in reducing unwanted smoking, the larger is the share of income spent on unwanted smoking, the larger is the benefit from taxation.

Moreover, the self-control benefits of taxation rise with the differences in price elasticity of demand across groups. Groups that are more price sensitive derive a larger self-control benefit from cigarette taxation, since higher taxes will more likely to cause them to quit. Thus, if lower income groups are more price sensitive, it further mitigates the regressivity of the tax. In fact, in the U.S., where lower income groups are about three times as price elastic as higher income groups, Gruber and Koszegi (2002) find that cigarette taxes are actually progressive for many parameter values, and for all parameter values are much less regressive than traditionally thought. While we cannot do a similar calibration exercise here, if we also find great differences in elasticities by income group in Canada, it suggests that parallel results may obtain in the Canadian context.

Results

Table 5 shows estimates of the demand equation by after-tax income quartile, and consumption quartile, in our FAMEX data; we show the results for all years and provinces, as 
excluding the smuggling provinces does not appear to have much of an impact on our FAMEX estimates. It is quite clear that in our data, as in the U.S., there is a much larger price elasticity of demand among lower income smokers. In the bottom income quartile, there is no effect of higher taxes on cigarette spending, with an estimated elasticity of demand close to -1 . This elasticity falls to -0.45 in the second quartile, and then to -0.31 in the third quartile before rising again to -0.36 in the top quartile. Divided by consumption quartiles, the elasticity pattern is similar, except that the big drop-off is between the second and third quartiles, and the elasticity rises significantly from the third to top quartiles.

In either case, in Table 5 there is a clear pattern of much higher elasticities for the lower income groups than for the higher income groups. These results are very consistent with those found in the U.S. by Gruber and Koszegi; indeed, the fall in elasticities as income/expenditure rise in Canada is somewhat steeper than in the U.S. This suggests that the type of calibration results obtained by Gruber and Koszegi for the U.S. might well hold in Canada as well, so that cigarette taxes are actually progressive (or not very regressive) under their alternative model of the smoking decision.

\section{Part VI: Effect on Alcohol Consumption}

Another key issue that has not been explored in the Canadian context, and has also been relatively unexplored in the U.S. context as well, is the substitutability or complementarity of cigarette and alcohol consumption. Ex ante, it is not clear if these activities will be complementary or substitutable. If there is a fixed demand for such "vice" activities, then when cigarette prices go up, individuals will substitute into drinking. But, if the activities are pursued 
together, or if individuals assign a fixed budget to such activities, then as cigarette prices go up, alcohol consumption may fall. In the U.S. context, Dee (1999) finds that smoking and drinking are complementary for youth; we are aware of no studies for overall consumption. There is also no evidence on this point of which we are aware for Canada.

If these activities are substitutes/complements, then it suggests that (a) the large tax increases of the early 1990s increased/decreased consumption of alcohol and (b) the smuggling that resulted decreased/increased consumption of alcohol. To the extent that consumption of alcohol is a "bad", such as smoking, this could imply potentially important spillover effects on welfare from cigarette taxation.

We can investigate this issue directly in both our legal sales and expenditure data, by modeling alcohol consumption as a function of cigarette prices. One problem that we face in the legal sales data, however, is that, unlike cigarettes, alcohol is not a uniform product that can simply aggregated; different products have very different alcoholic content. Thus, we rely specifically on beer consumption and prices, since this is a relatively homogenous good like cigarettes. Beer sales represent $80 \%$ of total alcohol sales, so that this should provide a good representation of the effects on alcohol consumption; our results are in fact quite similar if we use total volume of alcohol sales as well.

Our price measure is beer price per litre, which is computed by dividing the value of beer sales by the volume of sales, using data from CANSIM. Ideally, we would instrument beer prices with taxes as we do for cigarettes. Unfortunately, beer tax data are not available for our full sample period. Since our focus is on cigarette prices/taxes in any case, we therefore use uninstrumented beer prices. Our results for cigarette cross-price effects are insensitive to 
whether beer prices are included in the model.

When examining own price effects of cigarette prices on cigarette consumption, we expected (and found) an increase in the absolute value of the elasticity due to smuggling. But, for cross-price effects of cigarette prices on alcohol consumption, we expect a decrease in the absolute value of the elasticity from smuggling; a given price rise for cigarettes has less of an effect on alcohol consumption because its effects are muted by smuggling. Thus, if alcohol and cigarettes are substitutes, smuggling will reduce the the positive effect of cigarette prices on alcohol consumption; if they are complements, smuggling will mitigate the negative effect from rising cigarette prices.

The results of this analysis for legal beer sales are presented in the top panel of Table 6 . The regression framework is identical to equation (1), except that the dependent variable is now beer sales, and there are variables for both the cigarette and beer price. We find strong evidence here that cigarettes and alcohol are complements. There is a significant negative effect of cigarette prices on beer consumption, with a cross-price elasticity of -0.099 . The own price elasticity, which admittedly is less well identified since we do not have beer tax data, is roughly twice as large.

In the next column, we once again exclude the smuggling provinces. And, as expected, there is a rise in absolute value of the estimated cross-price elasticity, which roughly doubles when the smuggling provinces are excluded. This confirms that cigarettes and alcohol are complements. Moreover, it suggests that smuggling significantly increased the sales of alcohol, by increasing sales of cigarettes.

We next turn to an investigation of the impact of cigarette prices on alcohol in the 
FAMEX data. In FAMEX, unfortunately, we don't have beer expenditures, but rather only information on total alcohol expenditures. Once again, we follow an identical approach to that used earlier, with the exception of (a) changing the dependent variable to alcohol expenditures and (b) including a beer price regressor. The results are shown in the bottom panel of Table 6 .

In this case, we do not find any evidence for complementarity between cigarettes and alcohol; there is a positive effect of cigarette prices on alcohol consumption, but it is highly insignificant, both with the smuggling provinces in and with them out. At the same time, we find a much larger own price elasticity of alcohol consumption, although once again this coefficient is rendered somewhat suspect by the lack of satisfactory instrument.

It is unclear why we found consistent results across our data sets for own cigarette price effects and inconsistent results for cross-price effects. This may have something to do with the fact that we have beer consumption directly in the legal sales data, but only total alcohol expenditures in the FAMEX data; but, as noted above, our legal sales results are quite similar if we use total alcohol volumes. In any case, this leaves us unable to clearly conclude that cigarettes and alcohol are complements. But we can clearly conclude that these substances are not substitutes. This mitigates concerns that higher cigarette taxes will simply serve to drive up use of alcohol.

\section{Part VII: Conclusion}

A central parameter for designing public policy towards smoking is the price elasticity of demand for cigarettes. While there are numerous credible attempts to estimate this parameter in the U.S., there is much less evidence for Canada. Partly this is because the key period of price 
variation in Canada is a period of significant smuggling.

We have presented two approaches to surmounting the bias to estimated elasticities from smuggling. The first is to use legal sales data, and exclude the regions and years where the smuggling problem was the worst. The second is to use micro-data on consumer cigarette expenditures, where there is an opposite-signed bias from smuggling. Our estimated elasticities from these two approaches are strikingly similar, in the range of -0.45 to -0.47 . This suggests that a fairly reliable estimate of the elasticity of demand for cigarettes can be provided for Canada despite the large smuggling problem.

Further, we examine differences in the demand elasticities by income and consumption quartile. We find that demand elasticities are much higher for lower income or consumption quartiles, ranging from -1 for the lowest income quartile to -.3 for the highest income quartiles. These estimates are consistent with those found in the U.S. literature. They suggest, under the alternative time inconsistent model of smoking developed by Gruber and Koszegi $(2001,2002)$, that taxes on cigarettes may not be very regressive, as more price sensitive lower income groups derive a greater self-control benefit from higher cigarette prices.

Finally, we show that there is little reason to be concerned that higher taxes on cigarettes will drive consumers into drinking as an alternative source of "pleasure". Depending on the data set, we either find that cigarettes and alcohol are complements, or that their consumption is independent. Thus, smuggling may not have only served to raise cigarette consumption; it may have led to higher consumption of alternative "bads", such as alcohol, as well. 


\section{References}

Ainslie, G. (1992). Picoeconomics: The Strategic Interaction of Successive Motivational States within the Person. Cambridge, UK: Cambridge University Press.

Becker, G., and Murphy, K.M. (1988). “A Theory of Rational Addiction,” Journal of Political Economy, 96(4), pp.675-700.

Becker, G., Grossman, M., and Murphy, K.M. (1994). “An Empirical Analysis of Cigarette Addiction." American Economic Review, 84(3), pp.396-418.

Burns, J. (1992). "Looking to the Future," in Special Report: Business and Health, J. Burns, ed., pp.21-22, Medical Economics Publishing.

CDC (various years), "You Can Quit Smoking," Tobacco Information and Prevention Source, Webpage: www.cdc.gov/tobacco.

Canadian Manufacturer's Council (1993). Summary of Canadian and American Tobacco Sales, including sales of Canadian Contraband.

Chaloupka, Frank, and Warner, Kenneth E.(2001). “The Economics of Smoking”, in The Handbook of Health Economics, edited by Joseph P. Newhouse and Anthony J. Cuyler, New York: NorthHolland, Elsevier Science B.V., pp. 1539-1627.

Dee, Thomas (1999). "The Complementarity of Teen Smoking and Drinking," Journal Of Health Economics, (18)6, 769-793

Evans, W., Ringel, J, and Stech, D. (1999). "Tobacco Taxes and Public Policy to Discourage Smoking," in Tax Policy and the Economy, J. Poterba, Cambridge, MA: MIT press, p. 1-56.

Farrelly, Matthew C., Chaloupka, Frank, and Pechacek, Terry F. (2001). "The Impact of Tobacco Control Program Expenditures on Aggregate Sales: 1981-1998.” NBER Working Paper 8691, December 2001.

Galbraith, John W and Kaiserman, Murray (1997). "Taxation, Smuggling and Demand for Cigarettes in Canada: Evidence from Time-Series Data." Journal of Health Economics, 16(3), 287301.

Grabowski, J., and Hall, S.M. (1985). "Tobacco Use, Treatment Strategies and Pharmacological Adjuncts: An Overview," in Pharmacological Adjuncts in Smoking Cessation, J. Grabowski, and S. Hall, ed., National Institute on Drug Abuse Monograph 53, p. 1-13.

Green LW. (1997). “Taxes and the tobacco wars,.” Canadian Medical Association Journal, 156(2), 
pp. 205-6.

Gruber, J., and Koszegi, B. (2000). "Is Addiction "Rational”? Theory and Evidence.” NBER Working Paper 7507.

Gruber, J., and Koszegi, B. (2001). "Is Addiction "Rational”? Theory and Evidence." Quarterly Journal of Economics, 116(4), 1261-1305.

Gruber, J., and Koszegi, B. (2002). "A Theory of Government Regulation of Addictive Bads: Optimal Tax Levels and Tax Incidence for Cigarette Taxation," NBER Working Paper \#8777, February 2002.

Gruber, J., and Mullainathan, S. (2002). “Do Cigarette Taxes Make Smokers Happier?” NBER Working Paper \#8872, April 2002.

Gunby P. (1994). "Canada reduces cigarette tax to fight smuggling," Journal of the American Medical Association, 271(9), p. 647.

Hamilton V.H., Levinton C, St-Pierre Y., and Grimard, F. (1997a). "The effect of tobacco tax cuts on cigarette smoking in Canada." Canadian Medical Association Journal, 156(2), 187-91.

Hamilton V.H., Levinton C, St-Pierre Y., and Grimard, F. (1997b). “An Economic Analysis of Poor Smokers,” NHRDP Working Paper, Project No. 6605-4870-801, March.

Imasco Ltd. (1996). “Annual Report 1995”.

Laibson, D. (1997). “Golden Eggs and Hyperbolic Discounting,” Quarterly Journal of Economics, $112,443-477$.

Lanoie, Paul and Leclair, Paul (1998). "Taxation or Regulation: Looking for a Good Anti-smoking Policy." Economics Letters, 58(1), 85-89.

Lindquist, Avey, MacDonald, and Baskerville (1993). "1992 Contraband Estimate-An Update.” September $27^{\text {th }}, 1993$.

Lindquist, Avey, MacDonald, and Baskerville, "The Impact of Reducing Tobacco Taxes on the Contraband Market.” June $27^{\text {th }} 1994$.

Non-Smokers' Rights Association, "Cigarette Smuggling: A Global Weapon against Public Health Measures.”, http://www.nsra-adnf.ca/english/smuggling.html, November, 2001.

O’Donoghue, T., and Rabin, M. (1999). "Doing It Now or Later," American Economic Review, 89(1), 103-124. 
Prochaska, J.O., Crimi, P., Lapsanski, D., Martel, L., Reid, P (1982). "Self-Change Process, SelfEfficacy and Self-Concept in Relapse and Maintenance of Cessation and Smoking," Psychological Reports, 51, 983-990.

Reinhardt, Frank S; Giles, David E A.(2001). “Are Cigarette Bans Really Good Economic Policy?” Applied Economics, 33(11), 1365-68.

Robinson, Robert A. (1998). "Cigarette Smuggling: Information on Interstate and U.S.-Canadian Activity." Statement Before the Senate Democratic Task Force on Tobacco, May $4^{\text {th }}, 1998$.

Stephens, Thomas, Pederson, Linda L., Koval, John J., Kim, Charles (1997). "The relationship of cigarette prices and no-smoking bylaws to the prevalence of smoking in Canada." American Journal of Public Health, 87(9), 1519-1521.

Thursby, J., and Thursby, M. (2000). "Interstate Cigarette Bootlegging: Extent Revenue Losses, and Effects of Federal Intervention," National Tax Journal, 53(1), pp.59-77.

U.S. Department of Health and Human Services (1994). Preventing Tobacco Use Among Young People: A Report of the Surgeon General. National Center for Chronic Disease Prevention and Health Promotion, Office on Smoking and Health.

Yurekli, A., and Zhang, P. (2000). "The Impact of Clean Indoor-Air Laws and Cigarette Smuggling on Demand for Cigarettes: An Empirical Model," Health Economics, 9(2), 159-70. 


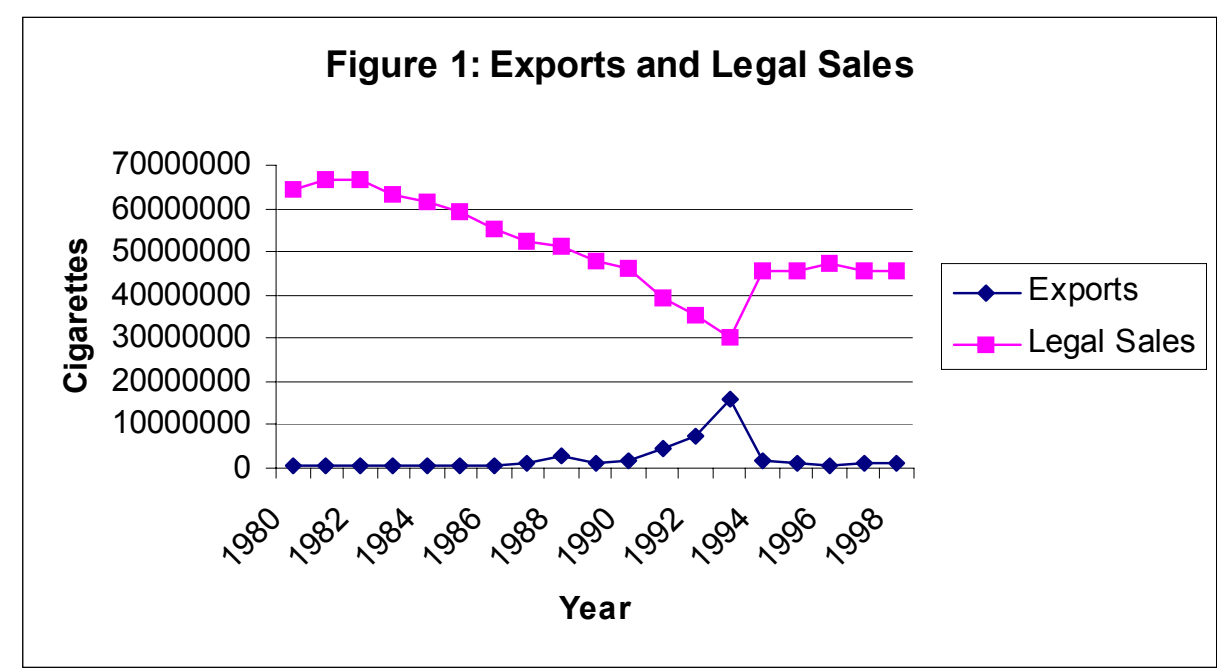

Source: National Clearing House on Tobacco and Statistics Canada 
Figure 2: Exports as a Proportion of Legal Sales

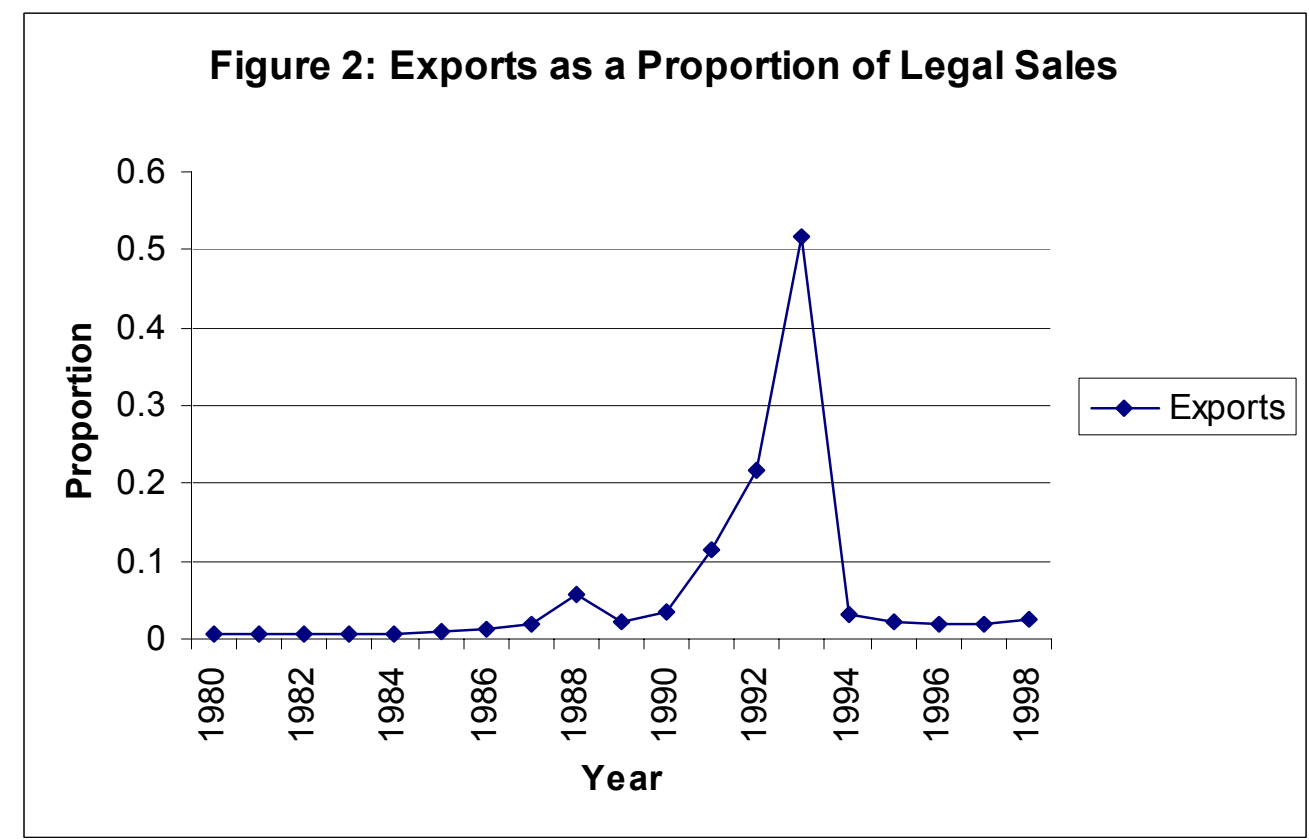

Source: National Clearing House on Tobacco and Statistics Canada 


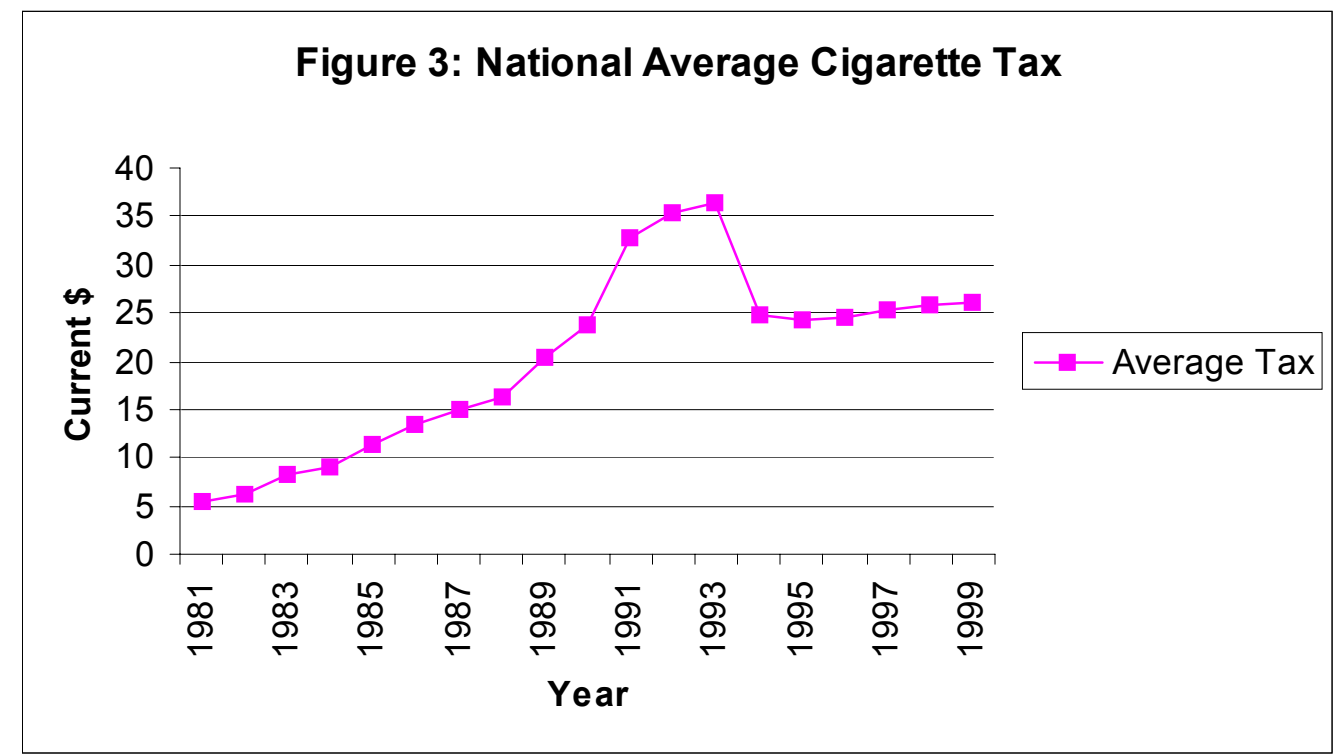

Source: National Clearing House on Tobacco and Statistics Canada 
Table 1: Cigarette Taxes, Price and Sales Over Time and Across Smuggling and Non-Smuggling Provinces

\begin{tabular}{|c|c|c|c|c|c|c|}
\hline & \multicolumn{2}{|c|}{$\begin{array}{c}\text { Per Capita Cigarette } \\
\text { Consumption for } \\
\text { Population aged } 15 \text { and } \\
\text { over }\end{array}$} & \multicolumn{2}{|c|}{$\begin{array}{l}\text { Tax Per } 200 \text { Cigarettes } \\
\text { (\$1992) }\end{array}$} & \multicolumn{2}{|c|}{$\begin{array}{c}\text { Price Per } 200 \text { Cigarettes } \\
(\$ 1992)\end{array}$} \\
\hline & $\begin{array}{c}\text { Non- } \\
\text { Smuggling } \\
\end{array}$ & Smuggling & $\begin{array}{c}\text { Non- } \\
\text { Smuggling } \\
\end{array}$ & Smuggling & $\begin{array}{c}\text { Non- } \\
\text { Smuggling }\end{array}$ & Smuggling \\
\hline $\begin{array}{c}1981 \\
\text { Levels }\end{array}$ & 3449.6 & 3371.76 & 8.99 & 8.87 & 15.89 & 16.44 \\
\hline $\begin{array}{l}\text { \% Change, } \\
1981-89\end{array}$ & -42.4 & -37.07 & 181.29 & 153.09 & 104.64 & 90.86 \\
\hline $\begin{array}{l}\text { \% Change, } \\
1990-93\end{array}$ & -25.199 & -40.65 & 55.62 & 55.63 & 50.219 & 49.44 \\
\hline $\begin{array}{c}\text { \% Change, } \\
\text { 1993-94 }\end{array}$ & -0.03 & 63.96 & -14.94 & -51.71 & -12.28 & -35.33 \\
\hline $\begin{array}{c}\text { \% Change, } \\
1995-99\end{array}$ & 5.75 & -5.61 & -5.26 & 17.31 & -0.36 & 13.49 \\
\hline $\begin{array}{c}1999 \\
\text { Levels }\end{array}$ & 1434.83 & 1873.21 & 28.79 & 18.04 & 40.66 & 31.59 \\
\hline
\end{tabular}

Source: Statistics Canada and National Clearinghouse on Tobacco and Health Program 


\begin{tabular}{|c|c|c|c|c|}
\hline \multicolumn{5}{|c|}{ Table 2: Means } \\
\hline & Mean & Std. Deviation & Minimum & Maximum \\
\hline \multicolumn{5}{|c|}{ Province/Year Data } \\
\hline $\begin{array}{l}\text { Cigarettes Per } \\
\text { Capita }\end{array}$ & 2118.8 & 813.18 & 817.82 & 4612.9 \\
\hline Real Price & 31.21 & 10.25 & 11.95 & 57.92 \\
\hline $\begin{array}{l}\text { Real Excise and } \\
\text { Sales Tax }\end{array}$ & 21.28 & 9.04 & 5.31 & 42.91 \\
\hline $\begin{array}{l}\text { Unemployment } \\
\text { Rate }\end{array}$ & 11.01 & 3.75 & 3.9 & 20.8 \\
\hline $\begin{array}{l}\text { Real Per Capita } \\
\text { Income }\end{array}$ & 15528.32 & 1911.41 & 10510.26 & 19641.91 \\
\hline \multicolumn{5}{|c|}{ FAMEX data } \\
\hline $\begin{array}{c}\text { Cigarette } \\
\text { Expenditures }\end{array}$ & 552.91 & 934 & 0 & 10800 \\
\hline $\begin{array}{c}\% \text { with any } \\
\text { Cig Expenditure }\end{array}$ & 44.14 & 50.00 & 0 & 1 \\
\hline $\begin{array}{l}\text { Mean Cig Expend } \\
\text { if }>0\end{array}$ & 1252.61 & 1048.75 & 1.84 & 10800 \\
\hline $\begin{array}{l}\text { Real Excise \& } \\
\text { Sales Tax }\end{array}$ & 20.93 & 8.54 & 8.14 & 39.04 \\
\hline Real Price & 31.51 & 10 & 14.81 & 51.59 \\
\hline Maritime Provinces & 0.24 & 0.43 & 0 & 1 \\
\hline Quebec & 0.17 & 0.38 & 0 & 1 \\
\hline Ontario & 0.2 & 0.4 & 0 & 1 \\
\hline Praries & 0.27 & 0.44 & 0 & 1 \\
\hline British Columbia & 0.12 & 0.33 & 0 & 1 \\
\hline $\begin{array}{l}\text { After-Tax HH } \\
\text { Income }\end{array}$ & 35714.42 & 22468.62 & -122915 & 356228.4 \\
\hline Family Size & 2.65 & 1.39 & 1 & 15 \\
\hline $\begin{array}{l}\text { Total Family } \\
\text { Expenditure }\end{array}$ & 42849.45 & 28182.89 & 57.09 & 356225.6 \\
\hline
\end{tabular}

Notes: Source is National Clearinghouse on Tobacco and Health Program and 1982-1998 FAMEX. For regions the mean represents the proportion of the survey in each cell. All dollar amounts are in 1992 Canadian dollars. 
Table 3: IV Estimates of Price Elasticity using Legal Sales Data

\begin{tabular}{ccc} 
& All Provinces & $\begin{array}{c}\text { Excluding Smuggling } \\
\text { Provinces/Years }\end{array}$ \\
\cline { 2 - 3 } Price Coefficient & -4995.5 & -3267.50 \\
Elasticity & $(701.58)$ & $(703.68)$ \\
Unemployment Rate & $\mathbf{- 0 . 7 2}$ & $\mathbf{- 0 . 4 7}$ \\
Per Capita Income & 37.02 & 30.66 \\
& $(16.39)$ & $(18.22)$ \\
Number of Obs & 23.93 & 20.80 \\
& $(4.78)$ & $(4.89)$ \\
\end{tabular}

Notes: Source: National Clearinghouse on Tobacco and Health Program and Statistics Canada. Results contained in column (1) is based on a sample of all ten Canadian provinces between 1981 to 1999. Column (2) consists of empirical estimates derived from British Columbia, Alberta, Saskatchewan, Manitoba, and Newfoundland between 1981 to 1999 and from Ontario, Quebec, New Brunswick, Nova Scotia, and Prince Edward Island between 1981 to 1989 and from 1995 to 1998. Standard errors are enclosed in parentheses below coefficient estimates. Cigarette price is instrumented using the cigarette excise and sales tax rate. Specifications include year and province dummies and province specific time trends. 
Table 4: IV Estimates of Price Elasticity using FAMEX data

\begin{tabular}{|c|c|c|c|c|c|c|}
\hline & \multicolumn{3}{|c|}{ All Provinces } & \multicolumn{3}{|c|}{ Excluding Smuggling Provinces/Years } \\
\hline & $\begin{array}{c}\text { Total } \\
\text { Spending }\end{array}$ & $\begin{array}{c}\text { Any } \\
\text { Spending }\end{array}$ & $\begin{array}{l}\text { Spending } \\
\text { if }>0\end{array}$ & $\begin{array}{c}\text { Total } \\
\text { Spending }\end{array}$ & $\begin{array}{c}\text { Any } \\
\text { Spending }\end{array}$ & $\begin{array}{l}\text { Spending } \\
\text { if }>0\end{array}$ \\
\hline Price & $\begin{array}{l}10.44 \\
(2.01)\end{array}$ & $\begin{array}{c}-0.00072 \\
(0.00)\end{array}$ & $\begin{array}{l}25.53 \\
(3.42)\end{array}$ & $\begin{array}{l}10.79 \\
(3.03)\end{array}$ & $\begin{array}{l}-0.0004 \\
(0.00)\end{array}$ & $\begin{array}{l}25.03 \\
(4.98)\end{array}$ \\
\hline Elasticity & -0.45 & -0.02 & -0.41 & -0.45 & -0.01 & -0.43 \\
\hline Quebec & $\begin{array}{l}52.88 \\
(21.90)\end{array}$ & $\begin{array}{l}0.063 \\
(0.01)\end{array}$ & $\begin{array}{l}-24.22 \\
(33.18)\end{array}$ & $\begin{array}{l}49.05 \\
(21.76)\end{array}$ & $\begin{array}{l}0.065 \\
(0.01)\end{array}$ & $\begin{array}{l}-32.17 \\
(32.59)\end{array}$ \\
\hline Ontario & $\begin{array}{l}24.14 \\
(20.97)\end{array}$ & $\begin{array}{l}0.024 \\
(0.01)\end{array}$ & $\begin{array}{c}-2.50 \\
(32.52)\end{array}$ & $\begin{array}{c}4.60 \\
(20.65)\end{array}$ & $\begin{array}{l}0.018 \\
(0.01)\end{array}$ & $\begin{array}{l}-24.30 \\
(31.72)\end{array}$ \\
\hline Prairie & $\begin{array}{l}-63.82 \\
(23.34)\end{array}$ & $\begin{array}{l}0.014 \\
(0.01)\end{array}$ & $\begin{array}{l}-159.37 \\
(36.92)\end{array}$ & $\begin{array}{l}-74.79 \\
(24.93)\end{array}$ & $\begin{array}{l}0.012 \\
(0.01)\end{array}$ & $\begin{array}{l}-171.70 \\
(39.42)\end{array}$ \\
\hline $\mathrm{BC}$ & $\begin{array}{r}-147.91 \\
(26.20)\end{array}$ & $\begin{array}{l}-0.042 \\
(0.01)\end{array}$ & $\begin{array}{l}-238.62 \\
(42.51)\end{array}$ & $\begin{array}{l}-159.69 \\
(26.65)\end{array}$ & $\begin{array}{l}-0.044 \\
(0.01)\end{array}$ & $\begin{array}{l}-252.42 \\
(42.76)\end{array}$ \\
\hline Male & $\begin{array}{c}7.47 \\
(6.85)\end{array}$ & $\begin{array}{l}0.0025 \\
(0.00)\end{array}$ & $\begin{array}{c}37.2 \\
(11.30)\end{array}$ & $\begin{array}{c}7.10 \\
(6.91)\end{array}$ & $\begin{array}{l}0.01 \\
0.00\end{array}$ & $\begin{array}{l}28.67 \\
(11.26)\end{array}$ \\
\hline $\begin{array}{c}\text { After-Tax } \\
\text { HH Inc }\end{array}$ & $\begin{array}{l}8.20 \mathrm{e}-03 \\
(3.71 \mathrm{e}-04)\end{array}$ & $\begin{array}{c}9.36 \mathrm{e}-07 \\
(2.06 \mathrm{e}-07)\end{array}$ & $\begin{array}{c}1.90 \mathrm{e}-02 \\
(6.90 \mathrm{e}-04)\end{array}$ & $\begin{array}{c}7.55 \mathrm{e}-03 \\
(3.73 \mathrm{e}-04)\end{array}$ & $\begin{array}{c}6.96 \mathrm{e}-07 \\
(2.12 \mathrm{e}-07)\end{array}$ & $\begin{array}{c}1.83 \mathrm{e}-02 \\
(6.90 \mathrm{e}-04)\end{array}$ \\
\hline $\begin{array}{l}\text { HH Inc } \\
\text { squared }\end{array}$ & $\begin{array}{l}-5.58 \mathrm{e}-08 \\
(2.98 \mathrm{e}-09)\end{array}$ & $\begin{array}{l}-1.39 \mathrm{e}-11 \\
(1.69 \mathrm{e}-12)\end{array}$ & $\begin{array}{l}-1.13 \mathrm{e}-07 \\
(5.94 \mathrm{e}-09)\end{array}$ & $\begin{array}{l}-5.16 \mathrm{e}-08 \\
(2.97 \mathrm{e}-09)\end{array}$ & $\begin{array}{l}-1.24 \mathrm{e}-11 \\
(1.69 \mathrm{e}-12)\end{array}$ & $\begin{array}{l}-1.11 \mathrm{e}-07 \\
(5.96 \mathrm{e}-09)\end{array}$ \\
\hline $\begin{array}{l}\text { Family } \\
\text { Size }\end{array}$ & $\begin{array}{c}72.7 \\
(2.66)\end{array}$ & $\begin{array}{l}0.047 \\
(0.00)\end{array}$ & $\begin{array}{c}35.2 \\
(4.29)\end{array}$ & $\begin{array}{l}71.7 \\
(2.67)\end{array}$ & $\begin{array}{l}0.047 \\
0.00\end{array}$ & $\begin{array}{l}34.96 \\
(4.26)\end{array}$ \\
\hline $\begin{array}{c}\text { Number of } \\
\text { Obs }\end{array}$ & 81479 & 81479 & 35965 & 72839 & 72839 & 32538 \\
\hline
\end{tabular}

Notes: Source: 1982-1998 Canadian Survey of Family Expenditure. Results contained in columns (1)-(3) are based on a sample of all ten Canadian provinces between 1981 to 1999. Columns (4)-(6) consists of empirical estimates derived from British Columbia, Alberta, Saskatchewan, Manitoba, and Newfoundland between 1981 to 1999 and from Ontario, Quebec, New Brunswick, Nova Scotia, and Prince Edward Island between 1981 to 1989 and from 1995 to 1998. Standard errors are enclosed in parentheses below coefficient estimates. Cigarette price is instrumented using the cigarette excise and sales tax rate. Specifications include year and province dummies and province specific time trends. Standard errors for the any spending regressions are robust. 
Table 5: IV Estimates of Elasticities by Income/Expenditure Group in FAMEX data Income Quartiles Expenditure Quartiles

\begin{tabular}{|c|c|c|c|c|}
\hline & $\begin{array}{c}\text { Ex-Ante } \\
\text { Spending as \% of } \\
\text { Income }\end{array}$ & $\begin{array}{c}\text { Effect of } \$ 1 \\
\text { Price } \\
\text { Increase }\end{array}$ & $\begin{array}{c}\text { Ex-Ante Spending } \\
\text { as } \% \text { of } \\
\text { Expenditure }\end{array}$ & $\begin{array}{l}\text { Effect of } \$ 1 \\
\text { Price } \\
\text { Increase }\end{array}$ \\
\hline Quartile 1 & 4.14 & $\begin{array}{c}0.07 \\
(2.78) \\
{[-0.99]}\end{array}$ & 2.28 & $\begin{array}{c}0.76 \\
(2.69) \\
{[-0.92]}\end{array}$ \\
\hline Quartile 2 & 2.16 & $\begin{array}{c}10.11 \\
(3.78) \\
{[-0.45]}\end{array}$ & 1.82 & $\begin{array}{c}4.84 \\
(3.72) \\
{[-0.73]}\end{array}$ \\
\hline Quartile 3 & 1.72 & $\begin{array}{c}15.96 \\
(4.43) \\
{[-0.31]}\end{array}$ & 1.43 & $\begin{array}{l}18.55 \\
(4.36) \\
{[-0.20]}\end{array}$ \\
\hline artile 4 & 1.01 & $\begin{array}{c}14.96 \\
(4.64) \\
{[-0.36]}\end{array}$ & 0.93 & $\begin{array}{l}15.24 \\
(4.73) \\
{[-0.37]}\end{array}$ \\
\hline
\end{tabular}

Notes: Source: 1982-1998 Canadian Survey of Family Expenditure.

Data is broken down into quartiles by after tax income and expenditure. Regressions control for region, year, sex, income, income squared, family size and regional time trends. First and third column give distribution of cigarette spending as a percentage of family after-tax income; second and fourth columns show group-specific effects of a $\$ 1$ increase in cigarette prices. Standard errors in parentheses. Price elasticities in square brackets. Cigarette price is instrumented using the cigarette tax rate. 
Table 6: IV Estimates of Cross-Price Elasticities of Alcohol Sales and Expenditures

\begin{tabular}{ccc}
\hline & All Provinces & $\begin{array}{c}\text { Excluding Smuggling } \\
\text { Provinces/Years }\end{array}$ \\
\hline Leer Price Coefficient & -6.53 & \\
Elasticity & $(3.20)$ & -8.05 \\
Cigarette Price Coefficient & $\mathbf{- 0 . 1 9}$ & $(3.81)$ \\
Elasticity & -28.7 & $\mathbf{- 0 . 2 2}$ \\
Mean of Beer Sales/Capita & $(14.0)$ & -49.2 \\
& $\mathbf{- 0 . 0 9 9}$ & $(23.0)$ \\
Beer Price Coefficient & 90.75 & $\mathbf{- 0 . 1 6}$ \\
& FAMEX Data on Alcohol Expenditures & 91.58 \\
Elasticity & 104.6 & $\mathbf{- 8 4 . 7}$ \\
\hline Expenditures & $(48.7)$ & $(56.1)$ \\
Eigarette Price Coefficient & $\mathbf{- 1 . 4 0}$ & $\mathbf{- 1 . 3 2}$ \\
& 2.96 & 0.35 \\
Mean of Alcohol & $(2.35)$ & $(3.42)$ \\
& $\mathbf{0 . 1 4}$ & $\mathbf{0 . 0 4}$ \\
& 630.6 & 629.5 \\
\hline
\end{tabular}

$\underline{\text { Notes: }}$ Sources as in previous tables. Standard errors in parentheses. Regressions include all additional covariates described in previous tables and footnotes to those tables. 